\title{
Geochronology Database for Central Colorado
}

Data Series 489 


\section{Geochronology Database for Central Colorado}

By T.L. Klein, K.V. Evans, and E.H. DeWitt

Data Series 489 


\title{
U.S. Department of the Interior \\ KEN SALAZAR, Secretary \\ U.S. Geological Survey \\ Marcia K. McNutt, Director
}

\section{U.S. Geological Survey, Reston, Virginia: 2010}

\author{
For more information on the USGS — the Federal source for science about the Earth, its natural and living resources, \\ natural hazards, and the environment, visit http://www.usgs.gov or call 1-888-ASK-USGS \\ For an overview of USGS information products, including maps, imagery, and publications, \\ visit http://www.usgs.gov/pubprod \\ To order this and other USGS information products, visit http://store.usgs.gov
}

\begin{abstract}
Any use of trade, product, or firm names is for descriptive purposes only and does not imply endorsement by the U.S. Government.

Although this report is in the public domain, permission must be secured from the individual copyright owners to reproduce any copyrighted materials contained within this report.
\end{abstract}

Suggested citation:

T.L. Klein, K.V. Evans, and E.H. DeWitt, 2009, Geochronology database for central Colorado: U.S. Geological Survey Data Series 489, 13 p. 


\section{Contents}

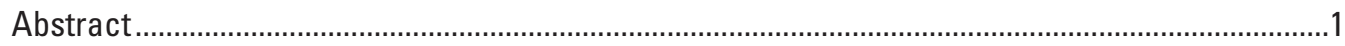

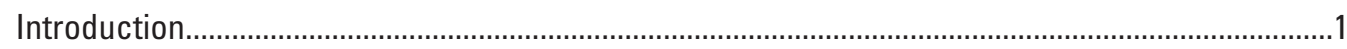

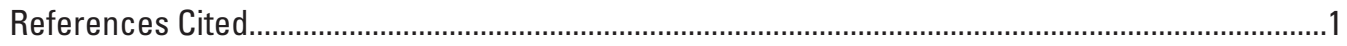

Geochronology database field names for spreadsheet...................................................................2

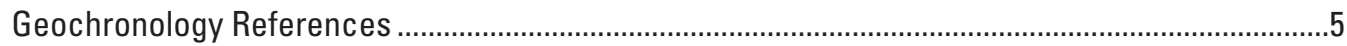

\section{Figure}

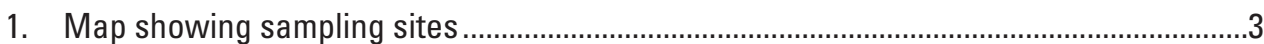

\section{Table}

1. Geochronology database for central Colorado

.. link 


\title{
Geochronology Database for Central Colorado
}

\author{
By T.L. Klein, K.V. Evans, and E.H. DeWitt
}

\section{Abstract}

This database is a compilation of published and some unpublished isotopic and fission track age determinations in central Colorado. The compiled area extends from the southern Wyoming border to the northern New Mexico border and from approximately the longitude of Denver on the east to Gunnison on the west. Data for the tephrochronology of Pleistocene volcanic ash, carbon-14, Pb-alpha, common-lead, and $\mathrm{U}-\mathrm{Pb}$ determinations on uranium ore minerals have been excluded.

\section{Introduction}

This database is a compilation of published and some unpublished isotopic and fission track age determinations in central Colorado. The compiled area extends from the southern Wyoming border to the northern New Mexico border and from approximately the longitude of Denver on the east to Gunnison on the west (fig. 1). This compilation was concentrated in the area of the Central Colorado Assessment Project and will be used to develop a geologic framework for the area as part of the compilation of a 1:100,000-scale geologic map for the study area. Data from outside the study area also were included to provide information on regional age relationships, and their compilation is, therefore, not as exhaustive. Data for the tephrochronology of Pleistocene volcanic ash, carbon-14, $\mathrm{Pb}$-alpha, common-lead, and $\mathrm{U}-\mathrm{Pb}$ determinations on uranium ore minerals have been excluded.

This database includes data from Wilson and Bryant (2006) for the Fort Collins, Estes Park, Denver West, and Bailey 1:100,000-scale quadrangles in the northern and central Front Range. These data were supplemented with recent age determinations, and some of the locations were updated.

The ages in this database that were determined using older decay constants have been corrected using the decay constants recommended by the International Union of Geological Sciences Subcommission on Geochronology (Steiger and Jaeger, 1977). K/Ar ages that were calculated with the older decay constant $\left({ }^{40} \mathrm{~K} / \mathrm{K}=1.19 \times 10^{-4} \mathrm{~mol} / \mathrm{mol}\right)$ and abundance constants were converted to the modern decay constant of $\left({ }^{40} \mathrm{~K} / \mathrm{K}=1.16 \times 10^{-4} \mathrm{~mol} / \mathrm{mol}\right)$ using the tables in Dalrymple
(1979). Older Rb-Sr ages that used the decay constant $\left({ }^{87} \mathrm{Rb} \lambda=1.39 \times 10^{-11} / \mathrm{yr}\right)$ were recalculated using the currently accepted constant $\left({ }^{87} \mathrm{Rb} \lambda=1.42 \times 10^{-11} / \mathrm{yr}\right)$. The original published ages (Age_Report) are given in table 1 as well as the recalculated ages (Age_Ma).

More than 2,000 age determinations are contained in the database. The distribution of data points is shown in figure 1 . The data are presented as a Microsoft Excel spreadsheet and an ESRI shapefile. The data are the same in each of the formats. The geographic coordinates are unprojected and use the North American Datum of 1927 (NAD 27).

In the original publications many sampling sites were not precisely located on geologic maps or by geographic coordinates. Locations for these samples were derived from written descriptions and sketch maps. Location points were digitized within the appropriate geologic unit by using the largest-scale published geologic base map available in the area of the sampling site. These sampling sites also were modified to place them along likely access routes (roads or trails) and in areas of likely outcrops within the appropriate geologic unit. Samples with approximate locations are so indicated in the comments field (Comments).

The boundary of the Central Colorado Assessment Project is included in this report as an ESRI polygon shapefile. Compilation of the data for this report is most complete within the study area. Use of this boundary file will allow the user to accurately determine the area where the data are most completely compiled.

\section{References Cited}

Dalrymple, G.B., 1979, Critical tables for conversion of K-Ar ages from old to new constants: Geology, v. 7, p. 558-560.

Steiger, R.H., and Jaeger, E., 1977, Subcommission on geochronology - Convention on use of decay constants in geoand cosmochronology: Earth and Planterary Science Letters v. 126, p. $359-362$.

Wilson, A.B., and Bryant, Bruce, 2006, Isotopic ages of rocks in the northern Front Range, Colorado: U.S. Geological Survey Open-File Report 2006-1051, 2 map sheets. 


\section{Geochronology database field names for spreadsheet}

FID - Program generated unique ID.

Unit_name - Lithology of sample.

Rock_Unit - Formal or informal rock unit name or geographic area.

Sample_No-Published field or laboratory number where available.

Quad_1_degree - USGS $1 / 2^{\circ} \times 1^{\circ}$ topographic quadrangle name.

Quad_24k-USGS 7.5-minute topographic quadrangle name.

Method-Geochronology method.

Mineral - Type of material analyzed.

Age_Ma-Geochronologic age, in millions of years (Ma).

Age_Uncert-Analytical precision.

Age_Report - Age as reported before recalculation using modern constants, in millions of years with analytical precision when given in reference.

Reference - Short form of determination reference, complete reference in "Geochronology References" section.

Comments - Comments on the age determination.

$X$ - Longitude in decimal degrees (NAD27).

$Y$ - Latitude in decimal degrees (NAD27).
Abbreviations
FT - fission track
$\mathrm{K} / \mathrm{Ar}$ - potassium/argon
$\mathrm{Nd}-\mathrm{Sm}$ - neodymium-samarium
$\mathrm{Rb}-\mathrm{Sr}$ - rubidium-strontium
$\mathrm{U}-\mathrm{Pb}$ - uranium-lead
${ }^{40} \mathrm{Ar} /{ }^{39} \mathrm{Ar}-{ }^{40} \operatorname{argon} /{ }^{39} \operatorname{argon}$ 


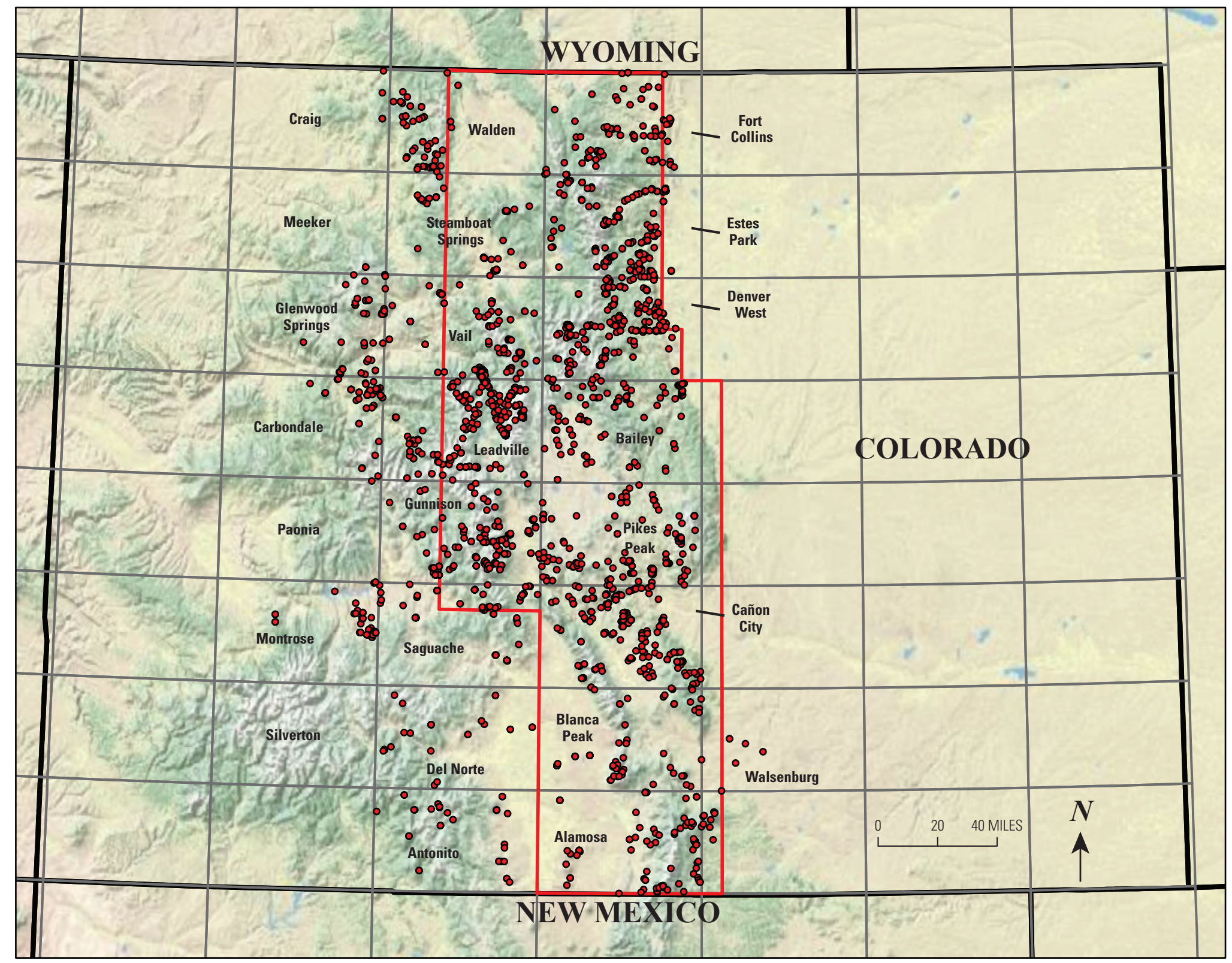

Figure 1. Sampling sites for published geochronology are represented by red filled circles. The location of Central Colorado Assessment Project area is represented by the red outline, $1 / 2^{\circ} \times 1^{\circ}$ topographic quadrangles are outlined in fine gray lines, and State boundaries are shown as coarse solid black lines. Names of the topographic quadrangles within and adjacent to the project area are shown. 
Table 1 - Geochronology Database for Central Colorado

See accompanying Microsoft Excel spreadsheet or ESRI shapefile.

Link to spreadsheet 


\section{Geochronology References}

Aldrich, L.T., Davis, G.L., Tilton, G.R., and Wetherill, G.W., 1956, Radioactive ages of minerals from the Brown Derby mine and the Quartz Creek granite near Gunnison, Colorado: Journal of Geophysical Research, v. 61, p. 215-232.

Aldrich, L.T., Wetherill, G.W., Davis, G.L., and Tilton, G.R., 1958, Radioactive ages of micas from granitic rocks by $\mathrm{Rb}-\mathrm{Sr}$ and $\mathrm{K}-\mathrm{A}[\mathrm{r}]$ [sic] methods: Transactions, American Geophysical Union, v. 39, p. 1124-1134.

Alexander, E.C., Mickelson, G.M., and Lanphere, M.A., 1978, MMhb-1: A new ${ }^{40} \mathrm{Ar}-{ }^{39} \mathrm{Ar}$ dating standard, in Zartman, R.E., ed., Short Papers of the Fourth International Conference, Geochronology, Cosmochronology, Isotope Geology 1978: U.S. Geological Survey Open-File Report 78-701, p. 6-8.

Aleinikoff, J.N. 1983, U-Th-Pb systematics of zircon inclusions in rock-forming minerals - A study of armoring against isotopic loss using the Sherman Granite of Colorado-Wyoming, USA: Contributions to Mineralogy and Petrology, v. 3, p. 259-269.

Aleinikoff, J.N., Reed, J.C., Jr., and DeWitt, Ed, 1993, The Mount Evans batholith in the Colorado Front Range-Revision of its age and reinterpretation of its structure: Geological Society of America Bulletin, v. 105, p. 791-806.

Armbrustmacher, T.J., and Hedge, C.E., 1982, Genetic implications of minor-element and Sr-isotope geochemistry of alkaline rock complexes in the Wet Mountains area, Fremont and Custer counties, Colorado: Contributions to Mineralogy and Petrology, v. 79, p. 424-435.

Baadsgaard, H., Lerbekmo, J.F., and McDougall, I., 1988, A radiometric age for the Cretaceous-Tertiary boundary based upon $\mathrm{K}-\mathrm{Ar}, \mathrm{Rb}-\mathrm{Sr}$, and $\mathrm{U}-\mathrm{Pb}$ ages of bentonites from Alberta, Saskatchewan, and Montana: Canadian Journal of Earth Sciences, v. 25, p. 1088-1097.

Baksi, A.K., Archibald, D.A., and Farrar, Edward, 1996, Intercalibration of ${ }^{40} \mathrm{Ar} /{ }^{39} \mathrm{Ar}$ dating standards: Chemical Geology, v. 129, p. 307-324.

Barbá, K.E., Nelson, E.P., Misantoni, Dean, Hitzman, M.W., and Layer, P.W., 2005, Structural controls on mineralized veins in the Sweet Home mine, Alma district, Colorado, in Rhoden, H.N., Steininger, R.C., and Vikre, P.G., eds., Geological Society of Nevada Symposium 2005: Windows to the World, Reno, Nevada, May 2005, p. 689-708.

Barker, Fred, Peterman, Z.E., Henderson, W.T., and Hildreth, R.E., 1974, Rubidium-strontium dating of the trondhjemite of Rio Brazos, New Mexico, and of the Kroenke granodiorite, Colorado: U.S. Geological Survey, Journal of Research, v. 2, p. 705-709.
Barovich, K.M., 1986, Age constraints on Early Proterozoic deformation in the northern Front Range, Colorado: Boulder, University of Colorado, Master's thesis, $49 \mathrm{p}$.

Beaty, D.W., Naeser, C.W., and Lynch, W.C., 1987, The origin and significance of the strata-bound, carbonate-hosted gold deposits at Tennessee Pass, Colorado: Economic Geology, v. 82, p. $2158-2178$.

Berger, G.W., 1975, ${ }^{40} \mathrm{Ar} /{ }^{39} \mathrm{Ar}$ step heating of thermally overprinted $\mathrm{Mg}_{3} \mathrm{Si}_{3} \mathrm{O}_{12}-\mathrm{Fe}_{3} \mathrm{Al}_{2} \mathrm{Si}_{3} \mathrm{O}_{12}$ hornblende and potassium feldspar from Eldora, Colorado: Earth and Planetary Science Letters, v. 26, p. 387-408.

Bickford, M.E., Cullers, R.L., Shuster, R.D., Premo, W.R., and Van Schmus, W.R., 1989, U-Pb zircon geochronology of Proterozoic and Cambrian plutons in the Wet Mountains and southern Front Range, Colorado, in Grambling, J.A., and Tewksbury, B.J., eds., Proterozoic geology of the Southern Rocky Mountains: Geological Society of America Special Paper 235, p. 49-64.

Bickford, M.E., Shuster, R.D., and Boardman, S.J., 1989, $\mathrm{U}-\mathrm{Pb}$ geochronology of the Proterozoic volcano-plutonic terrane in the Gunnison and Salida areas, Colorado, in Grambling, J.A., and Tewksbury, B.J., eds., Proterozoic geology of the Southern Rocky Mountains: Geological Society of America Special Paper 235, p. 33-48.

Bole, C.E., 1971, Potassium-argon ages, argon diffusion studies and petrography in the northern Front Range, Manhattan (Rustic quadrangle), Colorado: Columbus, Ohio State University, Master's thesis.

Bookstrom, A.A., 1989, The Climax-Alma granite batholith of Oligocene age and the porphyry molybdenum deposits of Climax, Colorado, U.S.A.: Engineering Geology, v. 27, p. 543-568.

Bookstrom, A.A., Naeser, C.W., and Shannon, J.R., 1987, Isotopic age determinations, unaltered and hydrothermally altered igneous rocks, north-central Colorado mineral belt: Isochron/West, no. 49, p. 13-20.

Bookstrom, A.A., Carten, R.B., Shannon, J.R., and Smith, R.P., 1988, Origins of bimodal leucogranite-lamprophyre suites, Climax and Red Mountain porphyry molybdenum systems-Petrologic and strontium isotopic evidence: Golden, Colorado School of Mines Quarterly, v. 83, p. 1-22.

Braddock, W.A., and Cole, J.C., 1990, Geologic map of Rocky Mountain National Park and vicinity: U.S. Geological Survey Miscellaneous Investigations Series Map I-1973, scale 1:50,000.

Braddock, W.A., and Peterman, Z.E., 1989, The age of the Iron Dike - A distinctive Middle Proterozoic intrusion in the northern Front Range of Colorado: The Mountain Geologist, v. 26, no. 4, p. 97-99. 
Brister, B.S., and McIntosh, W.C., 2004, Identification and correlation of Oligocene ignimbrites in well bores, Alamosa Basin (northern San Luis Basin), Colorado, by single-crystal laser-fusion ${ }^{40} \mathrm{Ar} /{ }^{39} \mathrm{Ar}$ geochronology of well cuttings, in Cather, S.M., McIntosh, W.C., and Kelley, S.A., eds., Tectonics, geochronology, and volcanism in the southern Rocky Mountains and Rio Grande Rift: New Mexico Bureau of Geology and Mineral Resources, Bulletin 160, p. 281-296.

Brookins, D.G., and Abashian, M.S., 1981, New K-Ar ages from the Eldora-Bryan stock and Idaho Springs Formation, Front Range, Colorado: Isochron/West, no. 32, p. 17.

Bruce, R.M., and Johnson, B.R., 1991, Reconnaissance geologic map of parts of the Zapata Ranch and Mosca pass quadrangles, Alamosa and Huerfano Counties, Colorado: U.S. Geological Survey Miscellaneous Field Studies Map MF-2168, scale 1:24,000.

Bryant, Bruce, and Naeser, C.W., 1980, The significance of fission-track ages of apatite in relation to the tectonic history of the Front and Sawatch Ranges, Colorado: Geological Society of America Bulletin, v. 91, p. 156-164.

Bryant, Bruce, Marvin, R.F., Naeser, C.W., and Mehnert, H.H., 1981, Ages of igneous rocks in the South Park-Breckenridge region, Colorado, and their relation to the tectonic history of the Front Range uplift, Chapter C, in Shorter contributions to isotope research in the western United States, 1980: U.S. Geological Survey Professional Paper 1199, p. 15-26.

Bryant, Bruce, Naeser, C.W., and Stegen, R.J., 1990, Reconnaissance fission-track geochronology of the Aspen mining district, central Colorado, in Beaty, D.W., Landis, G.P., and Thompson, T.B., eds., Carbonate-hosted sulfide deposits of the central Colorado mineral belt: Economic Geology Monograph No. 7, p. 301-307.

Caine, J.S., Nelson, E.P., Beach, S.T., and Layer, P.W., 2006, Structural fabrics, mineralization, and Laramide kinematics of the Idaho Springs-Ralston shear zone, Colorado Mineral Belt and central Front Range uplift: Mountain Geologist, v. 43 , p. 1-24.

Campbell, S.K., 1994, A geochemical and strontium isotopic investigation of Laramide and younger igneous rocks in central Colorado, with emphasis on the petrogenesis of the Thirtynine Mile volcanic field: Tallahassee, Florida State University, Ph.D. dissertation, 648 p.

Carlson, J. A., and Marsh, S.W., 1986, Discovery of the George Creek, Colorado kimberlite dikes, in C.B. Smith, compiler, Fourth International Kimberlite Conference, Perth, Western Australia, Abstracts: Geological Society of Australia, v. 16, p. 443-445.
Carr, D.R., and Kulp, J.L., 1957, Potassium-argon method of geochronometry: Geological Society of America Bulletin, v. 68 , p. $763-784$.

Cavosie, Aaron, and Selverstone, Jane, 2003, Early Proterozoic oceanic crust in the northern Colorado Front RangeImplications for crustal growth and the initiation of basement faults: Tectonics, v. 22, no. 2, 23 p.

Chualaowanich, Tawatchai, 1996, Geochemical characteristics and magma evolution of the Whitehorn stock, Chaffee, Fremont, and Park Counties, Colorado: Golden, Colorado School of Mines, Master's thesis, $156 \mathrm{p}$.

Church, S.E., and Bickford, M.E., 1971, Spontaneous fissiontrack studies of accessory apatite from granitic rocks of the Sawatch Range, Colorado: Geological Society of America Bulletin, v. 82, p. 1727-1734.

Coolbaugh, M.F., 1985, Geology and economic mineral potential of upper Browns Creek basin, Chaffee County, Colorado: Tucson, University of Arizona Master's thesis, 243 p.

Corbett, M.K., 1968, Tertiary volcanism of the SpecimenLulu-Iron Mountain area, north-central Colorado, in Epis, R.C., ed., Cenozoic volcanism in the southern Rocky Mountains: Golden, Colorado School of Mines Quarterly v. 63, no 3, p. 1-37.

Cunningham, C.G., and Naeser, C.W., 1975, The Italian Mountain intrusive complex, west-central Colorado, in Cohee, G.V., and Wright, W.B., eds., Changes in stratigraphic nomenclature by the U.S. Geological Survey, 1974: U.S. Geological Survey Bulletin 1405-A, p. A27-A28.

Cunningham, C.G., Naeser, C.W., and Marvin, R.F., 1977, New ages for intrusive rocks in the Colorado mineral belt: U.S. Geological Survey Open-File Report 77-573, 8 p.

Cunningham, C.G., Naeser, C.W., Marvin, R.F., Luedke, R.G., and Wallace, A.R., 1994, Age of selected intrusive rocks and associated ore deposits in the Colorado Mineral Belt: U.S. Geological Survey Bulletin 2109, 31 p.

DePaolo, D.J., 1981, Neodymium isotopes in the Colorado Front Range and crust-mantle evolution in the Proterozoic: Nature, v. 291, p. 193-196.

DeWitt, Ed, Zech, R.S., Chase, C.G., Zartman, R.E., Kucks, R.P., Bartelson, Bruce, Rosenlund, G.C., and Early, Drummond, III, 2002, Geologic and aeromagnetic maps of the Fossil Ridge area and vicinity, Gunnison County, Colorado: U.S. Geological Survey Geologic Investigations Series Map I-2738, scale 1:30,000.

Doe, B.R., and Pearson, R.C., 1969, U-Th-Pb chronology of zircons from the St. Kevin Granite, northern Sawatch Range, Colorado: Geological Society of America Bulletin, v. 80 , p. 2495-2502. 
Epis, R.C., and Chapin, C.E., 1968, Geologic history of the Thirtynine Mile volcanic field, Colorado, in Epis, R.C., ed., Cenozoic volcanism in the southern Rocky Mountains: Colorado School of Mines Quarterly, v. 63, no. 3, p. 51-85.

Evernden, J.F., Savage, D.E., Curtis G.H., and James, G.T., 1964, Potassium-argon dates and the Cenozoic mammalian chronology of North America: American Journal of Science, v. 262, p. $145-198$.

Fenton, M.D., and Faure, Gunter, 1970, Rb-Sr whole-rock age determinations of the Iron Hill and McClure Mountain carbonatite-alkalic complexes, Colorado: The Mountain Geologist, v. 7, p. 269-275.

Fridrich, C.J., DeWitt, Ed, Bryant, Bruce, Richard, S.M., and Smith, R.P., 1998, Geologic map of the Collegiate Peaks Wilderness Area and the Grizzly Peak caldera, Sawatch Range, central Colorado: U.S. Geological Survey Miscellaneous Investigations Series Map I-2565, scale 1:50,000.

Fridrich, C.J., Smith, R.P., DeWitt, Ed, and McKee, E.H., 1991, Structural, eruptive, and intrusive evolution of the Grizzly Peak caldera, Sawatch Range, Colorado: Geological Society of America Bulletin, v. 103, p. 1160-1177.

Galbraith, R.F., and Laslett, G.M., 1993, Statistical models for mixed fission-track ages: Nuclear Tracks and Radiation Measurements, v. 21, p. 459-470.

Gamble, B.M., 1979, Petrography and petrology of Mount Cumulus stock, Never Summer Mountains, Colorado: Boulder, University of Colorado Master's thesis, 75 p.

Geissman, J.W., Snee, L.W., Graaskamp, G.W., Carten, R.B., and Geraghty, E.P., 1992, Deformation and age of the Red Mountain intrusive system (Urad-Henderson molybdenum deposits), Colorado_Evidence from paleomagnetic and $\mathrm{Ar}^{40} / \mathrm{Ar}^{39}$ data: Geological Society of America Bulletin, v. 104, p. 1031-1047.

Giffin, C.E., and Kulp, J.L., 1960, Potassium-argon ages in the Precambrian basement of Colorado: Geological Society of America Bulletin, v. 71, p. 219-222.

Graubard, C.M., and Mattison, J.M., 1990, Syntectonic emplacement of the $\sim 1,440 \mathrm{Ma}$ Mt. Evans pluton and history of motion along the Idaho Springs-Ralston Shear Zone, central Front Range, Colorado: Geological Society of America Abstracts with Programs, v. 22, no. 6, p. 12.

Haggerty, S.E., Raber, Ellen, and Naeser, C.W., 1983, Fissiontrack determinations of kimberlite zircons: Earth and Planetary Science Letters, v. 63, no.1, p. 41-50.

Harrison, T.M., 1981, Diffusion of ${ }^{40} \mathrm{Ar}$ in hornblende: Contributions to Mineralogy and Petrology, v. 78, p. 324-331.
Hart, S.R., 1960, A study of mineral ages in a contact metamorphic zone, in Variations in isotopic abundances of strontium, calcium, and argon, and related topics: Massachusetts Institute of Technology, U.S. Atomic Energy Commission 6th Annual Progress Report, NYO-3941, p. 132-154.

Hart, S.R., 1964, The petrology and isotopic-mineral age relations of a contact zone in the Front Range, Colorado: Journal of Geology, v. 72, p. 493-525.

Hawley, C.C., Huffman, Claude, Jr., Hamilton, J.C., and Rader, L.F., Jr., 1966, Geologic and geochemical features of the Redskin Granite and associated rocks, Lake George beryllium area, Colorado: U.S. Geological Survey Professional Paper 550-C, p. C138-C147.

Heaman, L.M., Kjarsgaard, B.A., and Creaser, R.A., The timing of kimberlite magmatism in North America-Implications for global kimberlite genesis and diamond exploration: Lithos, v. 71, no. 2-4, p. 153-184.

Hedge, C.E., 1970, Whole-rock Rb-Sr age of the Pikes Peak batholith, Colorado: U.S. Geological Survey Professional Paper 700-B, p. B86-B89.

Helms, T.A., 2000, Structural and lithologic controls on gold mineralization in the Cresson Deposit, Cripple Creek District, Colorado: Golden, Colorado School of Mines, Master's thesis, $245 \mathrm{p}$.

Hill, B.M., and Bickford, M.E., 2001, Paleoproterozoic rocks of central Colorado-Accreted arcs or extended older crust?: Geology, v. 29, p. 1015-1018.

Hoblitt, R., and Larson, E.E., 1975, Paleomagnetic and geochronologic data bearing on the structural evolution of the northeastern margin of the Front Range, Colorado: Geological Society of America Bulletin, v. 86, no. 2, p. 237-242.

Hutchinson, R.M., 1960, Petrotectonics and petrochemistry of late Precambrian batholiths of central Texas and the north end of Pikes Peak Batholith, Colorado: Report of the Proceedings of the International Geological Congress, v. 21, part 14, p. 95-107.

Izett, G.A., 1966, Tertiary extrusive volcanic rocks in Middle Park, Grand County, Colorado: U.S. Geological Survey Professional Paper 500-B, p. B42-B46.

Izett, G.A., 1968, Geology of the Hot Sulphur Springs quadrangle, Grand County, Colorado: U.S. Geological Survey Professional Paper 586, 79 p.

Izett, G.A., 1974, Geologic map of the Trail Mountain Quadrangle, Grand County, Colorado: U.S. Geological Survey Geologic Quadrangle Map GQ-1156, scale 1:24,000. 
Izett, G.A., 1975, Late Cenozoic sedimentation and deformation in northern Colorado and adjoining areas, in Curtis, B.F., ed., Cenozoic history of the southern Rocky Mountains: Geological Society of America Memoir 144, p. 179-209.

Izett, G.A., and Obradovich, J.D., 2001, ${ }^{40} \mathrm{Ar} /{ }^{39} \mathrm{Ar}$ ages of Miocene tuffs in basin-fill deposits (Santa Fe Group, New Mexico, and Troublesome Formation, Colorado) of the Rio Grande Rift system: The Mountain Geologist, v. 38, p. $77-85$.

Jensen, E.P., 2003, Magmatic and hydrothermal evolution of the Cripple Creek gold deposit, Colorado, and comparisons with regional and global magmatic-hydrothermal systems associated with alkaline magmatism: Tucson, University of Arizona, Ph.D. dissertation, 978 p.

Jones III, J.V., 2005, Proterozoic tectonic evolution of southern Laurentia-New constraints from field studies and geochronology in southern Colorado and northern New Mexico, U.S.A.: Austin, University of Texas, Ph.D. dissertation, $202 \mathrm{p}$.

Jones III, J.V., and Connelly, J.N., 2006, Proterozoic tectonic evolution of the Sangre de Cristo Mountains, southern Colorado, U.S.A.: Rocky Mountain Geology, v. 41, p. $79-116$.

Kane, W.T., 1988, Trace element geochemistry and ${ }^{40} \mathrm{Ar} /{ }^{39} \mathrm{Ar}$ geochronology of epithermal mineralization in Four Mile Canyon, Boulder County, Colorado: Boulder, University of Colorado, Master's thesis, $112 \mathrm{p}$.

Kane, W.T., Atkinson, W.W., Jr., and Snee, L.W., 1988, Trace element geochemistry and $\mathrm{Ar} / \mathrm{Ar}$ geochronology of epithermal mineralization, Four Mile Canyon, Boulder County, Colorado: Geological Society of America Abstracts with Programs, v. 20, no. 7, p. A353.

Karimpour, M.H., 1982, Petrology, geochemistry, and genesis of the A.O. porphyry copper complex in Jackson and Grand Counties, northwestern Colorado: Boulder, University of Colorado Ph.D. thesis, 251 p.

Karimpour, M.H., and Atkinson, W.W., 1983, Petrogenesis of the A.O. porphyry copper complex in Jackson and Grand counties, northwestern Colorado: Global Tectonics and Metallogeny, v. 2, p. 15-27.

Kelley, K.D., Romberger, S.B., Beaty, D.W., Pontius, J.A., Snee, L.W., Stein, H.J., and Thompson, T.B., 1998, Geochemical and geochronological constraints on the genesis of Au-Te deposits at Cripple Creek, Colorado: Economic Geology, v. 93, p. 981-1012.
Kelley, S.A., 2005, Low-temperature cooling histories of the Cheyenne Belt and Laramie Peak shear zone, Wyoming, and the Soda Creek-Fish Creek shear zone, Colorado, in Karlstrom, K.E., and Keller, R.G., The Rocky Mountain region-An evolving lithosphere, tectonics, geochemistry, and geophysics: Geophysical Monograph, v. 154, p. 55-70.

Kelley, S.A., Chapin, C.E., and Corrigan, Jeff, 1992, Late Mesozoic to Cenozoic cooling histories of the flanks of the northern and central Rio Grande rift, Colorado and New Mexico: New Mexico Bureau of Mines and Mineral Resources Bulletin 145, 39 p.

Kelley, S.A., and Chapin, C.E., 2004, Denudation history and internal structure of the Front Range and Wet Mountains, Colorado, based on apatite fission-track thermochronology, in Cather, S.M., McIntosh, W.A., and Kelley, S.A., eds., Tectonics, geochronology, and volcanism in the southern Rocky Mountains and the Rio Grande rift: New Mexico Bureau of Geology and Mineral Resources Bulletin 160, p. 41-77.

Kirkham, R.M., and Heimsoth, C.M., 2003, Geologic map of the Fort Garland SW quadrangle, Costilla County, Colorado: Colorado Geological Survey Open-File Report 02-6, scale $1: 24,000$.

Kirkham, R.M., Lufkin, J.L., Lindsay, N.R., and Dickens, K.E., 2004, Geologic map of the La Valley quadrangle, Costilla County, Colorado: Colorado Geological Survey Open-File Report 04-8, scale 1:24,000.

Kirkham, R.M., Keller, J.M., Price , J.B., and Lindsey, N.R., 2005, Geologic map of the southern half of the Culebra Peak Quadrangle, Costilla and Las Animas Counties, Colorado: Colorado Geological Survey Open-File Report 05-3, 76 p., scale 1:24,000.

Kirkham, R.M., Keller, J.W., Houck, K.J., and Lindsay, N.R., 2006, Geologic map of the Fairplay East Quadrangle, Park County, Colorado: Colorado Geological Survey Open-File Report 06-9, scale 1:24,000.

Knox, K.L., 2005, The Never Summer igneous complexEvolution of a shallow magmatic system: Boulder, University of Colorado, Master's thesis, $54 \mathrm{p}$.

Kunk, M.J., Budahn, J.R., Unruh, D.M., Stanley, J.O., Kirkham, R.M., Bryant, B., Scott, R.B., Lidke, D.J., and Streufert, R.K., 2002, ${ }^{40} \mathrm{Ar} /{ }^{39} \mathrm{Ar}$ ages of late Cenozoic volcanic rocks within and around the Carbondale and Eagle collapse centers, Colorado - Constraints on the timing of evaporate-related collapse and incision of the Colorado River, in Kirkham, R.M., Scott, R.B., and Judkins, T.W., eds., Late Cenozoic evaporate tectonism and volcanism in west-central Colorado: Geological Society of America Special Paper 366, p. 213-234. 
Kunk, M.J., and Snee, L.W., 1998, ${ }^{40} \mathrm{Ar} /{ }^{39} \mathrm{Ar}$ age-spectrum data of Neogene and younger basalts in west central Colorado: U.S. Geological Survey Open-File Report 98-0243, 112 p.

Kunk, M.J., Winick, J.A., and Stanley, J.O., 2001, ${ }^{40} \mathrm{Ar} /{ }^{39} \mathrm{Ar}$ age-spectrum and laser fusion data for volcanic rocks in west central Colorado: U.S. Geological Survey Open-File Report 01-0472, 94 p.

Lanphere, M.A., Sawyer, D.A., and Fleck, R.J., 1990, High resolution ${ }^{40} \mathrm{Ar} /{ }^{39} \mathrm{Ar}$ geochronology of Tertiary volcanic rocks, Western U.S.A.: Abstracts-Geological Society of Australia, v. 27, p. 57.

Larson, E.E., and Drexler, J.W., 1988, Early Laramide mafic to intermediate volcanism, Front Range, Colorado: Colorado School of Mines Quarterly, v. 83, p. 41-52.

Larson, E.E., Ozima, M., and Bradley, W.C., 1975, Late Cenozoic basic volcanism in northwestern Colorado and its implications concerning tectonism and the origin of the Colorado River system, in Curtis, B.F., ed., Cenozoic history of the southern Rocky Mountains: Geological Society of America Memoir 144, p. 155-178.

Leader, J.W., and Jones, J.V., III, 2008, Age and tectonic significance of the ca. 1.4 Ga Browns Pass pluton, Collegiate Peaks Wilderness Area, Colorado: Geological Society of America Cordilleran Section and Rocky Mountain Section Joint Meeting Abstracts with Programs (March 19-21), Paper No. 16-27.

Lee, J.K.W., Onstott, T.C., Cashman, K.V., Cumbest, R.J., and Johnson, D., 1991, Incremental heating of hornblende in vacuo-Implications for ${ }^{40} \mathrm{Ar} /{ }^{39} \mathrm{Ar}$ geochronology and the interpretation of thermal histories: Geology, v. 19, p. 872-876.

Lester, A.P., 1992, Mineralogic, isotopic, and paleomagnetic variations in the contact aureole of the Audubon-Albion Stock, Front Range, Colorado: Boulder, University of Colorado $\mathrm{Ph} . \mathrm{D}$. dissertation, $190 \mathrm{p}$.

Lester, A.P., Larson, E.E., Farmer, G.L., Stern, C.R., and Funk, J.A., 2001, Neoproterozoic kimberlite emplacement in the Front Range, Colorado: Rocky Mountain Geology, v. 36, no. 1, p. 1-12.

Limbach, F.W., 1975, The geology of the Buena Vista area, Chaffee County, Colorado: Golden, Colorado School of Mines, Master's thesis, 98 p.

Lindsey, D.A., Andriessen, P.A.M., and Wardlaw, B.R., 1986, Heating, cooling, and uplift during Tertiary time, northern Sangre de Cristo Range, Colorado: Geological Society of America Bulletin, v. 97, p. 1133-1143.
Lipman, P.W., Steven, T.A., and Mehnert, H.H., 1970, Volcanic history of the San Juan Mountains, Colorado, as indicated by potassium-argon dating: Geological Society of America Bulletin, v. 81, p. 2329-2352.

Ludwig, K.R., and Young, E.J., 1975, Absolute age of disseminated uraninite in Wheeler Basin, Grand County, Colorado: U.S. Geological Survey Journal of Research, v. 3, no. 6, p. 747-751.

Ludwig, K.R., Wallace, A.R., and Simmons, K.R., 1985, The Schwartzwalder uranium deposit, II-Age of uranium mineralization and lead isotope constraints on genesis: Economic Geology, v. 80, p. 1858-1871.

Marshall, B.D., and DePaolo, D.J., 1982, Precise age determinations and petrogenetic studies using the K-Ca method: Geochimica et Cosmochimica Acta, v. 46, p. 2537-2545.

Marvin, R.F., and Cole, J.C., 1978, Radiometric ages-Compilation A, U.S. Geological Survey: Isochron/West, no. 22, p. 3-14.

Marvin, R.F., and Dobson, S.W., 1979, Radiometric agesCompilation B, U.S. Geological Survey: Isochron/West, no. 26, p. 3-32.

Marvin, R.F., Young, E.J., Mehnert, H.H., and Naeser, C.W., 1974, Summary of radiometric age determinations on Mesozoic and Cenozoic igneous rocks and uranium and base metal deposits in Colorado: Isochron/West, no. 11, p. 1-41.

Marvin, R.F., Mehnert, H.H., Naeser, C.W., and Zartman, R.E., 1989, U.S. Geological Survey radiometric agesCompilation "C", part five, Colorado, Montana, Utah, and Wyoming: Isochron/West, no. 53, p. 14-19.

McCallum, M.E., and Hedge, C.E., 1976, Rb-Sr ages of granitic rocks in the Rawah batholith, Medicine Bow Mountains, northern Colorado: Isochron/West, no. 17, p. 33-37.

McCallum, M.E., and Naeser, C.W., 1977, Fission-track ages of Tertiary intrusive rocks in the Manhattan mining district, northern Front Range, Colorado: Isochron/West, no. 18, p. 1-4.

McDowell, F.W., 1971, K-Ar ages of igneous rocks from the western United States: Isochron/West, no. 2, p. 1-16.

McIntosh, W.C., and Chapin, C.E., 2004, Geochronology of the central Colorado volcanic field, in Cather, S.M., McIntosh, W.C., and Kelley, S.A., eds., Tectonics, geochronology, and volcanism in the southern Rocky Mountains and Rio Grande rift: New Mexico Bureau of Geology and Mineral Resources Bulletin 160, p. 205-237. 
Miggins, D.P., 2002, Chronologic, geochemical, and isotopic framework of igneous rocks with the Raton Basin and adjacent Rio Grande Rift, south-central Colorado and northern New Mexico: Boulder, University of Colorado, Master's thesis, $417 \mathrm{p}$.

Miggins, D.P., Thompson, R.A., Pillmore, C.L., Snee, L.W., and Stern, C.R., 2002, Extension and uplift of the northern Rio Grande Rift-Evidence from ${ }^{40} \mathrm{Ar} /{ }^{39} \mathrm{Ar}$ geochronology from the Sangre de Cristo Mountains, south-central Colorado and northern New Mexico, in Menzies, M.A., Klemperer, S.L., Ebinger, C.J., and Baker, J., eds., Volcanic rifted margins: Geological Society of America Special Paper 362, p. $47-64$.

Misantoni, Dean, Silberman, M.L., and Lees, B.K., 1998, Geology of the Sweet Home mine and Alma district: Mineralogical Record, v. 29, p. 101-114.

Moorbath, Stephen, Hurley, P.M., and Fairbairn, H.W., 1967, Evidence for the origin and age of some mineralized Laramide intrusives in the southwestern United States from strontium isotope and rubidium-strontium measurements: Economic Geology, v. 62, p. 228-236.

Muehlberger, W.R., Hedge, C.E., Denison, R.E., and Marvin, R.F., 1966, Geochronology of the midcontinent region, United States: Journal of Geophysical Research, v. 71, p. 5409-5426.

Naeser, C.W., and Cunningham, C.G., 1976, Fission-track ages of zircons from three Tertiary porphyries near Tincup, Colorado: U.S. Geological Survey Open-File Report 76-831, $5 \mathrm{p}$.

Naeser, C.W., Izett, G.A., and White, W.A., 1973, Zircon fission-track ages from some middle Tertiary igneous rocks in northwestern Colorado: Geological Society of America Abstracts with Programs, v. 6, p. 498.

Naeser, C.W., Cunningham, C.G., and Beaty, D.W., 1990, Part III. Fission-track and fluid inclusion studies, in Beaty, D.W., ed., Origin of the ore deposits at Gilman, Colorado: Economic Geology Monograph 7, p. 219-228.

Naeser, C.W., Bryant, Bruce, Kunk, M.J., Kellogg, Karl, Donelick, R.A., and Perry, W.J., 2002, Tertiary cooling and tectonic history of the White River uplift, Gore Range, and western Front Range, central Colorado-Evidence from fission-track and ${ }^{39} \mathrm{Ar} /{ }^{40} \mathrm{Ar}$ ages, in Kirkham, R.M., Scott, R.B., and Judkins, T.W., eds., Late Cenozoic evaporate tectonism and volcanism in west-central Colorado: Geological Society of America Special Paper 366, p. 31-53.

Obradovich,, J.D., 2002, Geochronology of Laramide synorogenic strata in the Denver basin, Colorado, in Johnson, K.R., Raynolds, R.G., and Reynolds, M.L., eds., Paleontology and stratigraphy of Laramide strata in the Denver basin (Part 1): Rocky Mountain Geology, v. 37, no. 2, p. 165-171.
Obradovich, J.D., Mutschler, F.E., and Bryant, Bruce, 1969, Potassium-argon ages bearing on the igneous and tectonic history of the Elk Mountains and vicinity, Colorado-A preliminary report: Geological Society of America Bulletin, v. 80 , p. $1749-1756$.

Obradovich, J.D., and Cobban, W.A., 1975, A time-scale for the Late Cretaceous of the Western Interior of North America, in Caldwell, W.G.E., ed., The Cretaceous system in the Western Interior of North America: Geological Association of Canada Special Paper 13, p. 31-54.

Olson, J.C., Marvin, R.F., Parker, R.L., and Mehnert, H.H., 1977, Age and tectonic setting of lower Paleozoic alkalic and mafic rocks, carbonatites, and thorium veins in south-central Colorado: U.S. Geological Survey Journal of Research, v. 5, p. 673-687.

Ouimette, M.A., 1995, Petrology and geochemistry of Laramide and Tertiary igneous rocks in the Elk Mountains, Gunnison County, Colorado: University of Texas at El Paso, Ph.D. dissertation, $197 \mathrm{p}$.

Ouimette, M.A., Lawrence, D.P., and Shafiqullah, Mohammed, 1991, Petrology of the Late Cretaceous and Tertiary epizonal plutons in the vicinity of Taylor Park, Gunnison County, Colorado: Geological Society of America, Abstracts with Program, v. 23, no. 4, p. 55.

Pearson, R.C., and U.S. Bureau of Mines, 1980, Mineral resources of the Indian Peaks study area, Boulder and Grand Counties, Colorado: U.S. Geological Survey Bulletin 1463, $109 \mathrm{p}$.

Pearson, R.C., Tweto, Ogden, Stern, T.W., and Thomas, H.H., 1962, Age of Laramide porphyries near Leadville, Colorado: U.S. Geological Survey Professional Paper 450-C, p. C78-C80.

Pearson, R.C., Hedge, C.E., and Stern, T.W., 1966, Geochronology of the Saint Kevin Granite and neighboring Precambrian rocks, northern Sawatch Range, Colorado: Geological Society of America Bulletin, v. 77, p. 1109-1120.

Penn, B.S., 1994, An investigation of the temporal and geochemical characteristics, and the petrogenetic origins of the Spanish Peaks intrusive rocks of south-central Colorado: Golden, Colorado School of Mines, Ph.D. dissertation, $198 \mathrm{p}$.

Penn, B.S., and Lindsey, D.A., $2009,{ }^{39} \mathrm{Ar} /{ }^{40} \mathrm{Ar}$ dates for the Spanish Peaks intrusions in south-central Colorado: Rocky Mountain Geology, v. 44, p. 17-32.

Peterman, Z.E., Hedge, C.E., and Braddock, W.A., 1968, Age of Precambrian events in the northeastern Front Range, Colorado: Journal of Geophysical Research, v. 73, no. 6, p. 2277-2296. 
Peters, Lisa, 2004, ${ }^{40} \mathrm{Ar} /{ }^{39}$ Ar geochronology results from the La Valley quadrangle, Colorado: New Mexico Geochronological Research Laboratory, Internal Report No. NMGRLIR-424, 15 p.

Plymate, T.G., Moeglin, T.D., and Van Schmus, W.R., 2005, Petrology, geochemistry, and geochronology of Proterozoic granitoid and related rocks of the northern Mummy Range, north-central Colorado: Rocky Mountain Geology, v. 40, p. 115-155.

Premo, W.R., and Van Schmus, W.R., 1989, Zircon geochronology of Precambrian rocks in southeastern Wyoming and northern Colorado, in Grambling, J.A., and Tewksbury, B.J., eds., Proterozoic geology of the southern Rocky Mountains: Geological Society of America Special Paper 235, p. 13-32.

Pulfrey, R.J., 1971, Geology and geochemistry of the Mt. Antero granite and contiguous units, Chaffee County, Colorado: Stillwater, Oklahoma State University, Master's thesis, $84 \mathrm{p}$.

Rampe, J.S., Geissman, J.W., Melker, M.D., and Heizler, M.T., 2005, Paleomagnetic anad geochronologic data bearing on the timing, evolution, and structure of the Cripple Creek diatreme complex and related rocks, Front Range, Colorado, in Karlstrom, K.E., and Keller, G.R., eds., The Rocky Mountain Region-An evolving lithosphere-Tectonics, geochemistry, and geophysics: American Geophysical Union, Geophysical Monograph 154, p. 107-123.

Ranta, D.E., 1974, Geology, alteration, and mineralization of the Winfield (LaPlata) District, Chaffee County, Colorado: Golden, Colorado School of Mines, Ph.D. dissertation, $261 \mathrm{p}$

Reed, J.C., Jr., Bickford, M.E., Premo, W.R., Aleinikoff, J.N., and Pallister, J.S., 1987, Evolution of the early Proterozoic Colorado Province, constraints from U-Pb geochronology, with Supplementary Data 87-31: Geology, v. 15, no. 9, p. 861-865.

Renne, P.R., 1995, Excess ${ }^{40} \mathrm{Ar}$ in biotite and hornblende from the Noril'sk 1 intrusion, Siberia-Implications for the age of the Siberian Traps: Earth and Planetary Science Letters, v. 131 , p. $165-176$.

Renne, P.R., Swisher, C.C., Deino, A.L., Karner, D.B., Owens, T.L., and DePaolo, D.J., 1998, Intercalibration of standards, absolute ages and uncertainties in ${ }^{40} \mathrm{Ar} /{ }^{39} \mathrm{Ar}$ dating: Chemical Geology, v. 145, p. 117-152.

Rex, D.C., Guise, P.G., and Wartho, J.-A., 1993, Disturbed ${ }^{40} \mathrm{Ar}-{ }^{39} \mathrm{Ar}$ spectra from hornblendes: Thermal loss or contamination?: Chemical Geology, v. 103, p. 271-281.
Rice, C.M., Lux, D.R., and Macintyre, R.M., 1982, Timing of mineralization and related intrusive activity near Central City, Colorado: Economic Geology, v. 77, p. 1655-1666.

Romer, R.L., and Lueders, V., 2006, Direct dating of hydrothermal $\mathrm{W}$ mineralization- $\mathrm{U} / \mathrm{Pb}$ age for huebnerite $\left(\mathrm{MnWO}_{4}\right)$, Sweet Home Mine, Colorado: Geochemica Cosmochimica et Acta, v. 70, p. 4725-4733.

Sabin, T.G., 1994, Geochronology and isotope geochemistry of Early Proterozoic rocks exposed in portions of the Twin Peaks and Blanca Peak quadrangles, Alamosa, Costilla and Huerfano counties, Colorado: Lawrence, University of Kansas, Master's thesis, 94 p.

Sampson, S.D., and Alexander, E.C., 1987, Calibration of the interlaboratory ${ }^{40} \mathrm{Ar}-{ }^{39} \mathrm{Ar}$ dating standard, MMhb-1: Chemical Geology, v. 66, p. 27-34.

Sawatsky, D.L., 1967, Tectonic style along the Elkhorn thrust, eastern South Park and western Front Range, Colorado: Golden, Colorado School of Mines, D.Sc. thesis, 206 p.

Schärer, Urs, and Allègre, C.J., 1982, Uranium-lead system in fragments of a single zircon grain: Nature, v. 295, no. 5850 , p. 585-587.

Schassberger, H.T., 1972, K-Ar dates on intrusive rocks and alteration associated with molybdenum mineralization at Climax and Urad, Colorado, and Questa, New Mexico: Isochron/West, no. 3, p. 29.

Schoene, Blair, and Bowring, S.A., 2006, U-Pb systematics of the McClure Mountain syenite-Thermochronological constraints on the age of the ${ }^{40} \mathrm{Ar} /{ }^{39} \mathrm{Ar}$ standard MMhb: Contributions to Mineralogy and Petrology, v. 151, p. 615-630.

Schroeder, D.A., 1995, Geologic map of the Granby quadrangle, Grand County, Colorado: U.S. Geological Survey Geologic Quadrangle Map GQ-1763, scale 1:24,000.

Selverstone, Jane, Hodgins, Meghan, Aleinikoff, J.N., and Fanning, C.M., 2000, Mesoproterozoic reactivation boundary in the northern Colorado Front Range-Implications for $\sim 1.7$ and 1.4 Ga tectonism: Rocky Mountain Geology, v. 35, no. 2, p. 139-162.

Shannon, J.R., 1988, Geology of the Mount Aetna cauldron complex, Sawatch Range, Colorado: Golden, Colorado School of Mines, Ph.D. dissertation, 434 p.

Shaw, C.A., Snee, L.W., Selverstone, Jane, and Reed, J.C., Jr., 1999, ${ }^{40} \mathrm{Ar} /{ }^{39} \mathrm{Ar}$ thermochronology of Mesoproterozoic metamorphism in the Colorado Front Range: Journal of Geology, v. 107, p. 49-67. 
Shaw, C.A., Heizler, M.T., and Karlstrom, K.E., 2005, ${ }^{40} \mathrm{Ar} /{ }^{39} \mathrm{Ar}$ thermochronologic record of $1.45-1.35 \mathrm{Ga}$ intracontinental tectonism in the southern Rocky Mountains-Interplay of conductive and advective heating with intracontinental deformation, in Karlstrom, K.E., and Keller, G.R., eds., The Rocky Mountain region-An evolving lithosphere-Tectonics, Geochemistry, and Geophysics: American Geophysical Union, Geophysical Monograph 154, p. 163-184.

Siddoway, C.S., Givot, R.M., Bodle, C.D., and Heizler, M.T., 2000, Dynamic versus anorogenic setting for Mesoproterozoic plutonism in the Wet Mountains, Colorado-Does the interpretation depend on level of exposure?: Rocky Mountain Geology, v. 35, p. 91-111.

Simmons, E.C., and Hedge, C.E., 1978, Minor-element and Sr-isotope geochemistry of Tertiary stocks, Colorado Mineral Belt: Contributions to Mineralogy and Petrology, v. 67, p. 379-396.

Smith, C.D., 1979, Rb-Sr ages of various kimberlites: Cambridge, England, Abstracts of the kimberlite symposium II, p. 61-66.

Smith, D.R., Noblett, J., Wobus, R.A., Unruh, D., Douglass, J., Beane, R., Davis, C., Goldman, S., Kay, G., Gustavson, B., Saltoun, B., and Stewart, J., 1999, Petrology and geochemistry of late-stage intrusions of the A-type, mid-Proterozoic Pikes Peak batholith (central Colorado, USA) - Implications for petrogenetic models: Precambrian Research, v. 98, p. 271-305.

Smith, R.P., 1975, Structure and petrology of Spanish Peaks dikes, south central Colorado: Boulder, University of Colorado, Ph.D. dissertation, 270 p.

Snyder, G.L., 1980a, Geologic map of the northernmost Park Range and southernmost Sierra Madre, Jackson and Routt Counties, Colorado: U.S. Geological Survey Miscellaneous Investigations Series Map I-1113, scale 1:48,000.

Snyder, G.L., 1980b, Geologic map of the northernmost Gore Range and southernmost northern Park Range, Grand, Jackson, and Routt Counties, Colorado: U.S. Geological Survey Miscellaneous Investigations Series Map I-1114, scale $1: 48,000$.

Snyder, G.L., and Hedge, C.E., 1978, Intrusive rocks northeast of Steamboat Springs, Park Range, Colorado: U.S. Geological Survey Professional Paper 1041, 42 p.

Spell, T.L., and McDougall, I., 2003, Characterization and calibration of ${ }^{40} \mathrm{Ar} /{ }^{39} \mathrm{Ar}$ dating standards: Chemical Geology, v. 198, p. 189-211.
Stern, T.W., Phair, George, and Newell, M.F., 1971, Boulder Creek batholith, Colorado, Part I-Isotopic age of emplacement and morphology of zircon: Geological Society of America Bulletin, v. 82, p. 1615-1634.

Steven, T.A., Mehnert, H.H., and Obradovich, J.D., 1967, Age of volcanic activity in the San Juan Mountains, Colorado: U.S. Geological Survey Professional Paper 575-D, p. D47-D55.

Stormer, J.C., 1972, Ages and nature of volcanic activity on the southern High Plains, New Mexico and Colorado: Geological Society of America Bulletin, v. 83, p. 2443-2448.

Thomas, J.J., Shuster, R.D., and Bickford, M.E., 1984, A terrane of 1,350- to 1,400-m.y.-old silicic volcanic and plutonic rocks in the buried Proterozoic of the Mid-Continent and in the Wet Mountains, Colorado: Geological Society of America Bulletin, v. 95, no. 10, p. 1150-1157.

Taylor, R.B., Theobald, P.K., and Izett, G.A., 1968, MidTertiary volcanism in the central Front Range, Colorado, in Epis, R.C., ed., Cenozoic volcanism in the southern Rocky Mountains: Colorado School of Mines Quarterly, v. 63, no. 3 , p. 39-50.

Thompson, R.A., and Machette, M.N., 1989, Geologic map of the San Luis Hills area, Conejos and Costilla counties, Colorado: U.S. Geological Survey Miscellaneous Investigations Series Map I-1906, scale 1:50,000.

Thompson, T.B., and Arehart, G.B., 1990, Geology and the origin of ore deposits in the Leadville district, Colorado-Part I. Geologic studies of orebodies and wall rocks, in Beaty, D.W., Landis, G.P., and Thompson, T.B., eds., Carbonate-hosted sulfide deposits of the central Colorado mineral belt: Economic Geology Monograph no. 7, p. 130-155.

Thompson, R.N., Velde, D., Leaf, P.T., Morrison, M.A., Mitchell, J.G., Dickin, A.P., and Gibson, S.A., 1997, Oligocene lamproite containing an Al-poor, Ti-rich biotite, Middle Park, Northwest Colorado, USA: Mineralogical Magazine, v. 61, no. 4, p. 557-572.

Toulmin, P., III, and Hammarstrom, J.M., 1990, Geology of the Mount Aetna volcanic center, Chaffee and Gunnison Counties, Colorado: U.S. Geological Survey Bulletin 1864, $44 \mathrm{p}$.

Tweto, Ogden, and Lovering, T.S., 1977, Geology of the Minturn 15-minute quadrangle, Eagle and Summit Counties, Colorado: U.S. Geological Survey Professional Paper 956, $96 \mathrm{p}$. 
Tweto, Ogden, Steven, T.A., Hail, W.J., Jr., and Moench, R.H., 1976, Preliminary geologic map of the Montrose $1^{\circ}$ x $2^{\circ}$ quadrangle, southwestern Colorado: U.S. Geological Survey Miscellaneous Field Investigations Map MF-761, scale 1:250,000.

Van Loenen, R.E., Lee, G.K., Campbell, D.L., and Thompson, J.R., 1989, Mineral resource potential of Mount Massive Wilderness, Lake County, Colorado: U.S. Geological Survey Bulletin 1636, 18 p.

Vera, R.H., and Van Schmus, W.R., 1974, Geochronology of some Precambrian rocks of the southern Front Range, Colorado: Geological Society of America Bulletin, v. 85, p. $77-82$.

Wallace, A.R., 1993, Summary of isotopic geochronology for the Leadville $1^{\circ}$ x $2^{\circ}$ quadrangle, central Colorado: 3.5 inch diskette containing dates and supporting data: U.S. Geological Survey Open-File Report 93-615.

Wallace, A.R., 1995, Isotopic geochronology of the Leadville $1^{\circ} \times 2^{\circ}$ quadrangle, west-central Colorado-Summary and discussion: U.S. Geological Survey Bulletin 2104, 51 p.

Wallace, A.R., 1997, Geologic map of the Fort Garland quadrangle, Costilla County, Colorado: U.S. Geological Survey Miscellaneous Field Studies Map MF-2312-E, scale $1: 24,000$.
Wallace, C.A., and Keller, J.W., 2003, Geologic map of the Castle Rock Gulch Quadrangle, Chaffee and Park Counties, Colorado: Colorado Geological Survey Open-File Report 01-1, scale 1:24,000.

Wetherill, G.W., and Bickford, M.E., 1965, Primary and metamorphic Rb-Sr chronology in central Colorado: Journal of Geophysical Research, v. 70, p. 4669-4686.

White, W.H., Bookstrom, A.A., Kamilli, R.J., Ganster, M.W., Smith, R.P., Ranta, D.E., and Steininger, R.C., 1981, Character and origin of Climax-type molybdenum deposits: Economic Geology, Seventy-fifth Anniversary Volume, p. 270-316.

Widmann. B.L., Kirkham, R.M., Keller, J.W., Poppert, J.T., and Price, J.B., 2005, Geologic map of the Como Quadrangle, Park County Colorado: Colorado Geological Survey Open-File Report 05-4, scale 1:24,000.

Young, E.J., 1972, Laramide-Tertiary intrusive rocks of Colorado: U.S. Geological Survey Open-File Report 72-0456, scale 1:500,000.

Zielinski, R.A., Peterman, Z.E., Stuckless, J.S., Rosholt, J.N., and Nkomo, I.T., 1981, The chemical and isotopic record of rock-water interaction in the Sherman Granite, Wyoming and Colorado: Contributions to Mineralogy and Petrology, v. 78, p. 209-219.
Central Mineral Resources Team

Publishing support provided by:

Denver Publishing Service Center

For more information concerning this publication, contact:

Team Chief Scientist, USGS Central Mineral Resources

Box 25046, Mail Stop 973

Denver, CO 80225

(303) 236-1562

Or visit the Central Mineral Resources Team Web site at:

http://minerals.cr.usgs.gov/ 